\title{
KELEWATAN PENGENDALIAN KES FASAKH DALAM ASPEK UNDANG-UNDANG TATACARA MAL: KAJIAN KES DI SELANGOR
}

\section{Delay of Fasakh Proceedings in Shariah Court Civil Procedure: A Case Study in Selangor}

\author{
Mohd Zaidi Md Zain@Zakaria ${ }^{1}$ \\ Raihanah Hj. Abdullah²
}

\begin{abstract}
Studies relating to the weaknesses of the civil procedures in particular on the process of fasakh litigation are still relevant for review and debate. This is due to the fact that there have been complaints and reports lodged by the public over the delay in hearing of fasakh claims under provisions relating to civil procedures. Therefore, the case study was conducted to find out the extent of the issues as a result of the civil procedure in fasakh cases based on three methods of data collection namely observation, interviews and documentation. The results clearly showed that indeed there are factors in the delay of cases involving civil procedures. Whereby, the researcher suggests certain recommendations based on the data collected.
\end{abstract}

1 Ph.D Candidate, Department of Shariah and Law, Academy of Islamic Studies, University of Malaya, 50603 Kuala Lumpur, dmzaidizain@hotmail.com

2 Professor, Department of Shariah and Law, Academy of Islamic Studies, University of Malaya, 50603 Kuala Lumpur, raihanah@um.edu.my 
Keywords: fasakh, delay, Shariah civil procedure, Shariah Court

\section{PENGENALAN}

Fasakh ialah melepaskan ikatan perkahwinan antara suami dan isteri melalui kuasa hakim di atas sebab-sebab yang diharuskan oleh hukum syarak. Pembubaran melalui dikri mahkamah ini juga dikenali sebagai tafriq dalam Bahasa Arab. ${ }^{3}$ Fasakh hanya boleh dilaksanakan oleh pihak yang berkuasa sahaja seperti hakim Mahkamah Syariah apabila terdapat alasan-alasan tertentu yang telah diperuntukkan oleh Seksyen 53 Enakmen Undang-undang Keluarga Islam (Negeri Selangor) 2003 iaitu mengenai perintah untuk membubarkan perkahwinan atau fasakh.

Oleh yang demikian, pihak-pihak yang memfailkan kes ke mahkamah hendaklah melalui proses berdasarkan peruntukan Undang-undang Tatacara Mal bagi memastikan perjalanan kes berjalan lancar mengikut prosedur yang telah ditetapkan. Namun begitu, telah berlaku rungutan yang berterusan khususnya daripada kaum wanita mengenai pelbagai masalah berkenaan dengan prosedur tuntutan fasakh yang menyebabkan kelewatan kepada perbicaraan dan penyelesaian kes.

Sehubungan dengan itu, kajian ini berfokus kepada permasalahan tuntutan fasakh di Mahkamah Syariah dengan menumpukan kepada aspek Undangundang Tatacara Mal dengan membuat analisis terhadap peruntukan di dalam Enakmen Tatacara Mal Mahkamah Syariah Negeri Selangor tahun 2003. Pemilihan negeri Selangor dilakukan kerana ia merupakan antara negeri terawal yang mengguna pakai penyelarasan Undang-undang Tatacara Mal yang dicadangkan oleh Majlis Raja-raja dan jumlah tuntutan fasakh yang paling tinggi berbanding dengan negeri-negeri lain. Menurut statistik yang dikeluarkan oleh Jabatan Kehakiman Syariah Selangor (JAKESS) ${ }^{4}$ kes perceraian secara umum di Selangor telah berlaku peningkatan pada tahun 2014 sebanyak 11 297, tahun 2015 sebanyak 11873 dan meningkat sebanyak 12578 pada tahun 2016. Seterusnya, penulis juga telah memperoleh data perceraian secara terkini daripada JAKESS mengenai kes fasakh yang difailkan antara tahun 2010-2017 yang berjumlah 12 059. Daripada data tersebut, penulis mendapati

3 Harun Din, al-Furqah bayn al-Zawjayn, li al-Mawāni al-Sharī'ah Fiqhan wa Qadā'an (Kuala Lumpur: Percetakan Waatan, 1984), 119.

4 Statistik pendaftaran kes fasakh, Rekod Mahkamah no. Permohonan 273, Jabatan Kehakiman Syariah Selangor di bawah enakmen kebebasan maklumat (negeri Selangor) 2011, 10 Disember 2018. 
bahawa berlaku peningkatan pendaftaran kes fasakh pada setiap tahun kecuali pada tahun 2013 dan 2017 yang direkodkan mengalami penurunan.

\section{PERNYATAAN MASALAH}

Aduan mengenai kelewatan kes perceraian termasuk kes fasakh sering kedengaran di media cetak, elektronik serta media alternatif tanpa kunjung padam. Perkara ini telah menyebabkan timbulnya kritikan yang berlebihan dan tidak benar berkenaan isu diskriminasi terhadap wanita yang berlaku di Mahkamah Syariah. ${ }^{5}$ Kajian yang dijalankan oleh Md Zawawi dan Abdul Rahman Khudzri ${ }^{6}$ di Mahkamah Syariah seluruh Malaysia menunjukkan bahawa kes fasakh mengambil tempoh masa yang panjang untuk diselesaikan dan menimbulkan banyak kesukaran kepada pihak isteri. Pelbagai usaha telah dilakukan oleh pihak berwajib untuk mengatasi masalah tersebut seperti membuat pindaan kepada undang-undang Mahkamah Syariah bermula sejak awal tahun $2003^{7}$ dan yang terbaru ialah pelaksanaan perceraian secara fast track di Mahkamah Syariah Negeri Selangor pada tahun 2015. ${ }^{8}$ Proses fast track yang dilaksanakan tersebut sememangnya mengambil masa yang singkat iaitu selama kurang dari enam jam sahaja. Namun begitu, ia tidak menyelesaikan masalah berkaitan dengan kelewatan proses perbicaraan di mahkamah apabila tiada persetujuan pihak-pihak. ${ }^{9}$

Walaupun terdapat pindaan kepada undang-undang yang melibatkan Mahkamah Syariah, namun masih terdapat peruntukan-peruntukan tertentu yang sebenarnya menjadi punca kepada permasalahan tersebut tidak disentuh di dalam pindaan. Hal ini dapat dilihat sebagaimana hasil kajian oleh Raihanah

$5 \quad$ Farah Safura Muhammud \& Aminuddin Ruskam, 'A Review of Discrimination Against Women in Shariah Courts,' Sains Humanika, vol. 5/3 (2015): 9-14.

6 Md Zawawi Abu Bakar \& Wan Ab Rahman Khudzri Wan Abdullah, 'An Analysis on the Issues of the Rights of Spouses in the Islamic Family Law in Malaysia,' International Journal of Business and Social Research, vol. 1/1 (2011): 94-108.

7 Pindaan-pindaan tersebut berdasarkan kepada cadangan penyeragaman undangundang Mahkamah Syariah seluruh Malaysia yang dipersetujui oleh Majlis Rajaraja pada 1 Ogos 1997.

8 Proses kes cerai fast track yang dilancarkan oleh Mahkamah Syariah Negeri Selangor pada 9 Julai 2015 hanyalah melibatkan kes perceraian secara persetujuan bersama sahaja yang dahulunya mengambil masa dua hingga empat minggu, tetapi melalui proses ini kes perceraian boleh diselesaikan dalam tempoh enam jam sahaja.

9 Mohd Zaidi Md Zain, 'Tuntutan Fasakh: Kajian Dari Perspektif Undang-Undang Tatacara Mal,' Journal of Shariah Law Research, vol. 3/1 (2018): 1-34. 
Abdullah ${ }^{10}$ di dalam artikel yang bertajuk "Penangguhan kes di Mahkamah Syariah: Cabaran dan Penyelesaian" menyimpulkan antara lain faktor yang menyumbang kepada kelewatan kes ialah berkait dengan undang-undang prosedur iaitu proses penyampaian saman. Kelewatan perceraian fasakh juga boleh berlaku akibat daripada banyak penangguhan kes dengan alasan kelemahan dalam pengemukaan bukti dan juga kegagalan mematuhi kehendak undang-undang prosedur seperti kajian yang diketuai oleh Siti Zubaidah. ${ }^{11}$

Selanjutnya kajian oleh Suwaid Tapah ${ }^{12}$ membincangkan kesan-kesan kelemahan prosedur dan pelaksanaannya ke atas kes-kes yang dibicarakan, termasuklah isu kelewatan dan kesulitan yang dihadapi oleh pihak-pihak yang bertikai di mahkamah. Manakala hasil kajian projek Intensification of Research in Priority Areas (IRPA) Universiti Malaya (UM) yang diketuai oleh Narizan Abdul Rahman, ${ }^{13}$ telah mengenal pasti bahawa terdapat permasalahan dalam undang-undang prosedur yang antara lain merangkumi aspek-aspek permasalahan seperti peruntukan tidak lengkap, pertindihan bidang kuasa, penggunaan borang dan peruntukan undang-undang tidak selaras serta tidak jelas dari segi prosedur perbicaraan, saman di luar bidang kuasa serta terdapat juga peruntukan undang-undang tersebut tidak difahami atau diketahui oleh pihak-pihak yang bertikai di mahkamah.

Kajian lain oleh Suzaini Mohd Saufi dan Najibah Mohd Zin ${ }^{14}$ turut menghuraikan mengenai masalah proseduryang mendapatiproses penyampaian saman yang tidak konsisten di dalam pengamalan yang sebenar iaitu dengan ketiadaan prosedur operasi yang standard yang akan melambatkan prosiding kes fasakh terutamanya. Oleh itu, dapatan dalam kajian kes ini adalah sebagai

10 Raihanah Abdullah, 'Penangguhan Kes di Mahkamah Syariah: Cabaran dan Penyelesaian,' Jurnal Syariah, vol.17/1 (2009): 17-19.

11 Siti Zubaidah Ismail, Ilhaamie Abdul Ghani Azmi \& Zulfikri Yasoa, 'Justice Delayed is Justice Denied?: Divorce Case Management in Malaysian Shariah Court' Proceeding International Conference on Management (Penang: ICM, 2011), 977-987.

12 Suwaid Tapah, 'Undang-Undang Mal di Malaysia,' dalam Mahkamah Syariah di Malaysia: Pencapaian dan Cabaran, ed. Ahmad Hidayat Buang (Kuala Lumpur: Penerbit Universiti Malaya, 2005), 23-24.

13 Narizan Abdul Rahman, 'Isu-Isu dan Masalah Perundangan Mahkamah Syariah' (Kertas kerja Penyelidikan Intensification of Research in Priority Areas, Balai Ilmu Akademi Pengajian Islam, Universiti Malaya, 30 Ogos 2005), 1-25.

14 Suzaini Mohd Saufi \& Najibah Mohd Zin, 'An Empirical Study on Women's Plight in Ta'liq and Fasakh Proceedings in the Malaysian Syariah Court' (Paper presented, 1st International Conference on Women and Children Legal and Social Issues, Subang, Selangor, 17-18 October 2016). 
langkah awal untuk mengetahui permasalahan sebenar yang berlaku dengan lebih mendalam dan cadangan yang diperlukan untuk mengatasinya.

\section{OBJEKTIF KAJIAN}

Kajian ini dijalankan bagi menjelaskan dua objektif kajian seperti yang berikut:

a) Mengenal pasti faktor-faktor kelewatan prosiding fasakh dari aspek pemakaian undang-undang Tatacara Mal di Selangor.

b) Menganalisis peruntukan dalam Undang-undang Tatacara Mal bersabit dengan tuntutan fasakh.

\section{METODOLOGI KAJIAN}

Penulis memilih penyelidikan kualitatif melalui pendekatan kajian kes untuk mendalami sesuatu isu, peristiwa atau fenomena dalam konteks yang sebenar. ${ }^{15}$ Kajian kes dilaksanakan secara menyeluruh (holistik) iaitu melibatkan pelbagai sumber maklumat untuk menghuraikan dan menjelaskan kepada sesuatu peristiwa yang berlaku secara mendalam. ${ }^{16}$ Penulis menjalankan kajian kes instrumental yang bersesuaian dengan objektif bagi menganalisis secara kritis permasalahan dan memahami secara mendalam untuk menghuraikan mengapa kelewatan dalam tuntutan kes fasakh berlaku di Mahkamah Syariah.

Metode pengumpulan data yang digunakan dalam kajian kes ialah pemerhatian, temu bual dan dokumentasi. Metode pemerhatian dilaksanakan untuk merekodkan situasi sebenar yang berlaku di Mahkamah Syariah dalam pengurusan kes fasakh. Pemerhatian ini bertujuan untuk mengkaji interaksi yang kompleks dalam latar sosial yang sebenar (semula jadi) ${ }^{17}$ di mana penulis memainkan peranan sebagai peserta penuh dan melibatkan diri secara aktif dalam aktiviti yang dikaji. ${ }^{18}$ Pemerhatian dijalankan terhadap dua kes yang melibatkan proses tuntutan fasakh bermula daripada kes difailkan sehingga keputusan dikeluarkan oleh mahkamah, iaitu dari tahun 2011-2016 untuk kes

15 Crowe Sarah et al., 'The Case Study Approach,' BMC Research Medical Methodology, vol. 11/100 (2011): 1-9.

16 Chua Yan Piaw, Kaedah Penyelidikan (Kuala Lumpur: McGraw-Hill Education, 2014), 131.

17 Othman Lebar, Penyelidikan Kualitatif: Pengenalan kepada Teori dan Metode (Perak: Penerbit Universiti Pendidikan Sultan Idris, 2015), 232.

18 Chua Yan Piaw, Kaedah Penyelidikan, 178-179. 
pertama dan dari tahun 2012-2017 untuk kes kedua. Kes pertama melibatkan plaintif Fathiah binti Mohamad Rejab@Hashim dan defendan Ahmad Fauzi bin Haji Saian. Plaintif (pihak isteri) diwakili oleh peguam syarie Mohd Rafie bin Shafie, manakala penulis merupakan peguam syarie yang mewakili pihak suami (defendan). Kes ini diputuskan oleh hakim Tuan Muhamad Nazri $\mathrm{Hj}$ Basrawi. Manakala kes kedua plaintif adalah Masayu binti Mohamad Husain yang diwakili oleh peguam syarie Halimatunsa'diah binti Abu Ahmad dan defendan Wan Johairiza bin Wan Ab. Rahman yang diwakili oleh penulis. Kes ini diputuskan oleh hakim Tuan Saharuddin bin Selamat dan kedua-dua kes ini belum diterbitkan.

Metode temu bual merupakan kaedah yang amat penting dalam kajian kes untuk mendapatkan maklumat yang relevan, lebih jelas, sahih dan tanpa sebarang tokok tambah serta dapat menjamin keaslian sesuatu data khususnya fakta yang berbentuk amalan daripada mereka yang terlibat secara langsung dalam mengendalikan kes fasakh di Mahkamah Syariah sebagai keperluan dalam kajian serta menyokong data pemerhatian. Protokol temu bual yang disediakan mengandungi lima jenis soalan untuk protokol temu bual, iaitu soalan pembuka, pengenalan, transisi, kunci dan penutup. ${ }^{19}$ Temu bual secara individu telah dijalankan terhadap 11 peguam syarie di Selangor untuk memperoleh permasalahan utama yang melibatkan prosedur tatacara mal. Rujukan kepada sumber bertulis yang mempunyai hubung kait dengan tajuk yang ingin dikaji turut diperlukan seperti rekod mahkamah, akta-akta dan enakmen-enakmen, jurnal hukum, arahan-arahan amalan, keputusan fatwa negeri dan kebangsaan serta dokumen-dokumen yang lain.

Penulis menjalankan pengesahan inventori soalan separuh berstruktur oleh empat orang pakar bidang syariah untuk menguji kesahan muka dan kesahan kandungannya dalam memastikan ketepatan konstruk dan kejelasan kandungan $^{20}$ yang menepati matlamat kajian. Untuk meninggikan darjah kesahan konstruk, pemerhatian perlu dibuat dengan melihat fenomena yang sama dengan maksimum perbezaan dimensi atau perspektif. ${ }^{21}$ Penggunaan teknik triangulasi seperti pungutan data dari temu bual dan analisis dokumen bukan hanya menambah bukti malahan berupaya untuk mengesahkan maklumat yang diperolehi dari data pemerhatian. ${ }^{22}$ Memandangkan kajian

19 Richard A. Krueger, Focus Groups: A Practical Guide for Applied Research (Thousand Oaks: Sage Publications, 1994), 36-45.

20 Theresa Kline, Psychological Testing: A Practical Approach to Design and Evaluation (California: Sage Publication, 2005).

21 Kenneth D. Bailey, Methods of Social Research. New York: Fee Press, 1978), 155.

22 Suseela Malakolunthu, 'Pengumpulan dan Analisis Data Kualitatif: Satu Imbasan,' dalam Penyelidikan Kualitatif, ed. Marohaini Yusoff (Kuala Lumpur: Penerbit Universiti Malaya, 2001), 121-132. 
kualitatif bergantung kepada data subjektif, intepretif dan kontekstual, ${ }^{23}$ maka tumpuan diberikan kepada beberapa jenis proses untuk memastikan kesahan seperti dalam jadual berikut:

Jadual 1: Prosedur Kesahan dalam Lensa Kualitatif

\begin{tabular}{lll}
\hline \multicolumn{1}{c}{ Lensa Kualitatif } & \multicolumn{1}{c}{ Prosedur Kesahan } \\
\hline Lensa Penulis & - Refleksiviti penulis \\
Lensa Peserta Kajian & - Memanjangkan tempoh berada di lapangan \\
$\begin{array}{l}\text { Lensa Orang Luar Kajian } \\
\text { (Penilai/Pembaca) }\end{array}$ & - Deskripsi (huraian) yang tebal dan terperinci \\
\hline
\end{tabular}

Sumber: Creswell dan Miller ${ }^{24}$

Data yang diperoleh daripada tiga sumber iaitu pemerhatian, temu bual dan penelitian dokumen dianalisis menggunakan perisian program komputer iaitu QSR NVivo Versi 12 untuk mengasingkan, menyusun dan mencari maklumat dalam petikan serta dapat membandingkan kod-kod yang berbeza. ${ }^{25}$ Memandangkan kajian kes melibatkan penerangan yang mendalam terhadap sesuatu fenomena diikuti oleh analisis data mengikut tema atau kategori ${ }^{26}$ pengesahan oleh tiga orang panel pakar yang dilantik terhadap tema yang dibina dan pengiraan Cohen Kappa terhadap tahap persetujuan pakar diperlukan. ${ }^{27}$

\section{PENGOLAHAN DATA}

Semua data dan maklumat yang diperoleh melalui metode-metode di atas kemudiannya diolah, dikembangkan dan disimpulkan menggunakan beberapa kaedah analisis, iaitu metode induktif, deduktif dan komparatif. Data yang diperoleh dengan bantuan perisian Nvivo menunjukkan terdapat dua tema, tiga sub tema dan enam kategori (Rajah 1). Dua tema yang terhasil ialah

23 Auerbach Carl \& Louise B. Silverstein, Qualitative Data: An Introduction to Coding and Analysis (New York: NYU Press, 2003).

24 John W. Creswell \& Dana L. Miller, 'Determining Validity in Qualitative Inquiry,' Theory into Practice Journal, vol. 39/3 (2000): 124-130.

25 Greg Guest et al., 'Choosing Qualitative Data Analysis Software,' in Applied Thematic Analysis (Thousand Oaks, CA: Sage, 2012), 217-238.

26 Robert E. Stake, The Art of Case Study Research: Perspective in Practice (Thousand Oaks, CA: Sage Publishing, 1995), 143.

27 Robert C. Bogdan \& Sari K. Biklen, Qualitative Research for Education: An Introduction to Theory and Methods (Boston: Allyn \& Bacon, 2003), 14-16. 
faktor-faktor kelewatan dan cadangan-cadangan penambahbaikan diikuti tiga sub tema yang terdiri daripada pra perbicaraan, semasa perbicaraan dan pasca perbicaraan. Manakala enam kategori melibatkan proses penyampaian saman, pengurusan kes, kaedah memberikan keterangan, tempoh masa perbicaraan, penetapan tempoh masa dan alasan penghakiman serta penggantungan pelaksanaan perintah.

Rajah 1: Penghasilan Tema, Sub Tema dan Kategori dari Kelewatan Kes Fasakh

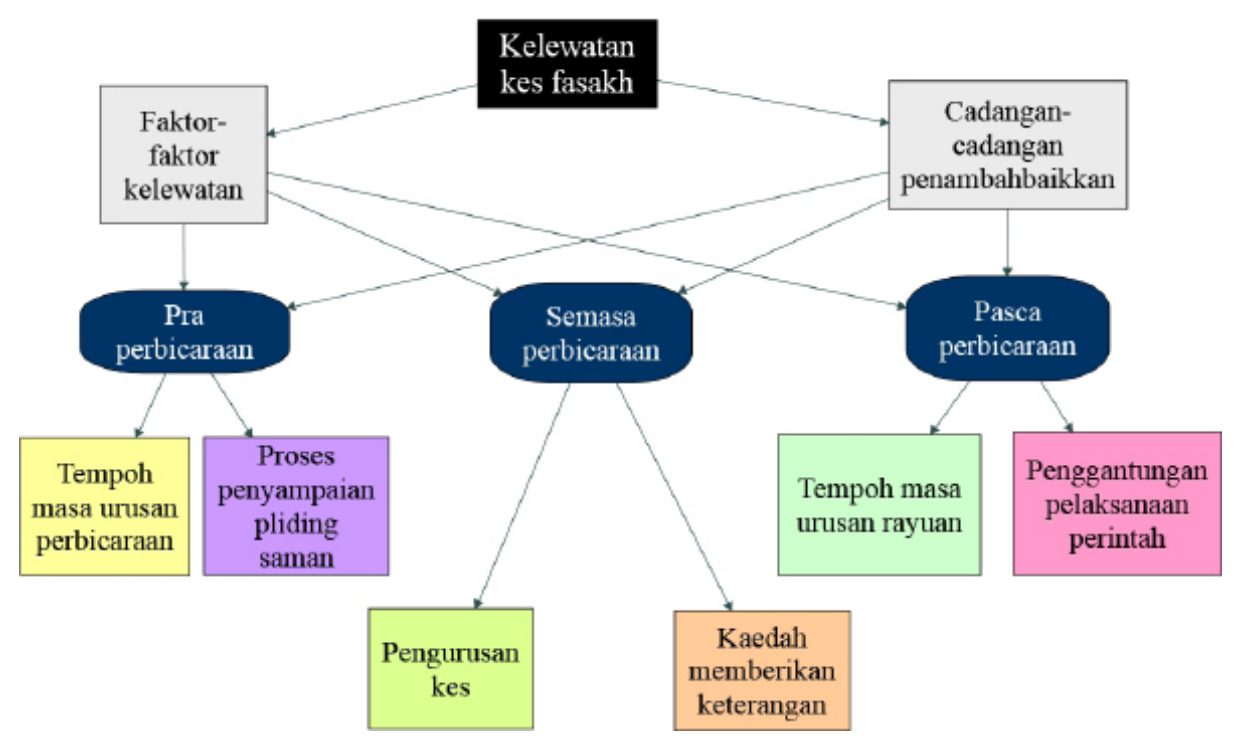

Sumber: Analisis Nvivo

\section{Tema 1: Faktor-faktor Kelewatan dalam Tuntutan Kes Fasakh}

Rajah 2 menunjukkan peta konsep faktor-faktor kelewatan kes fasakh bagi menjawab objektif kajian yang pertama iaitu mengenal pasti faktor-faktor kelewatan prosiding kes fasakh dari aspek pemakaian Undang-undang Tatacara di Selangor yang mewakili Malaysia. 
Rajah 2: Peta Konsep Faktor-Faktor Kelewatan Kes Fasakh

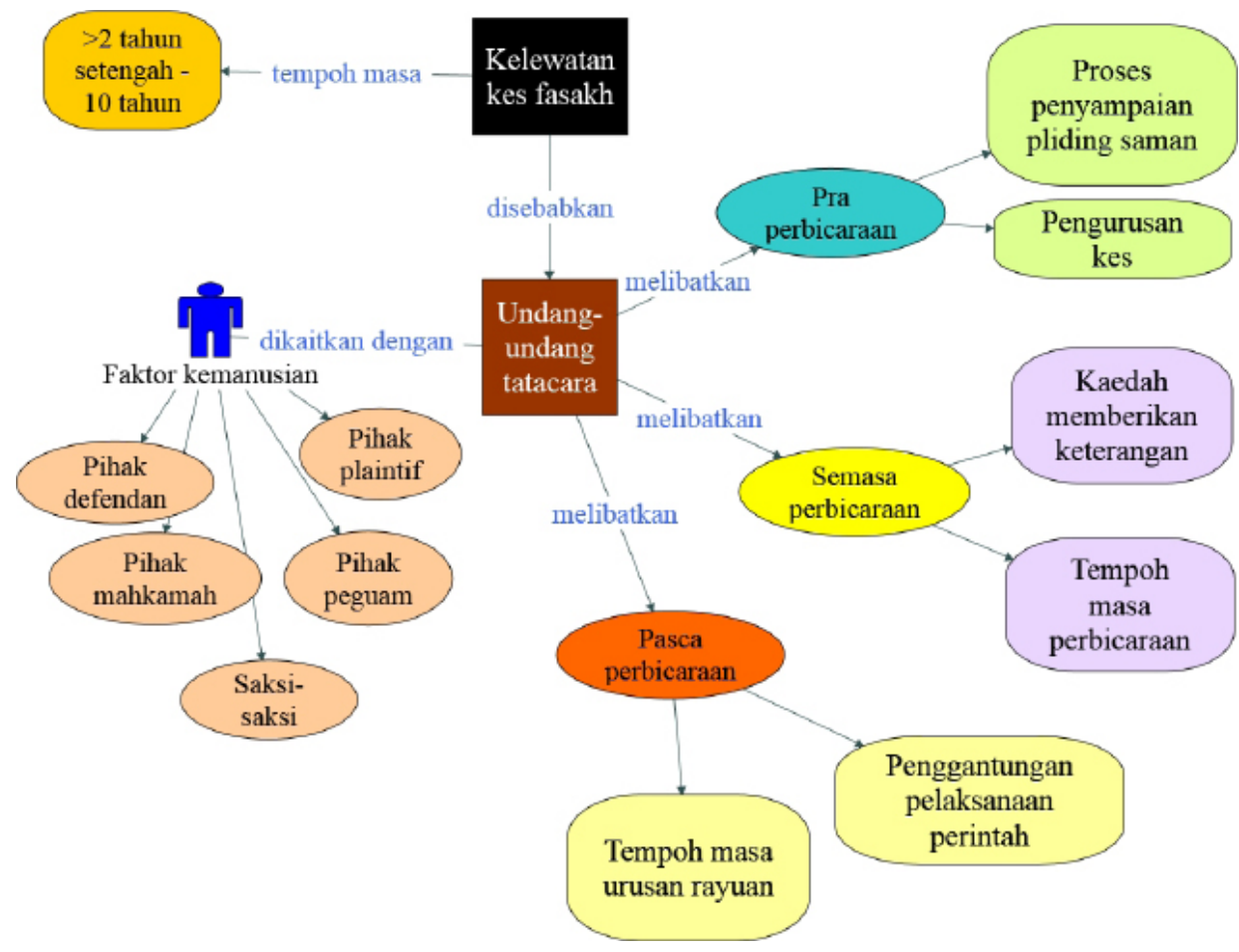

Sumber:Analisis Nvivo

\section{Sub tema 1: Peringkat Pra Perbicaraan}

Terdapat dua kategori di bawah sub tema peringkat pra perbicaraan iaitu proses penyampaian pliding saman dan pengurusan kes. Perkara ini dijelaskan secara mendalam seperti di bawah:

\section{Kategori Proses Penyampaian Pliding Saman}

Berdasarkan kepada pemerhatian kes pertama dan kedua, penulis mendapati tidak terdapat apa-apa masalah dalam proses penyampaian saman kerana plaintif dan defendan berada di alamat yang sama. Namun begitu, penulis mendapati masalah dalam proses penyampaian saman akan timbul apabila pihak defendan enggan untuk menerima saman. Walau bagaimanapun, keengganan seseorang untuk menerima atau menandatangani sesuatu saman atau dokumen itu tidaklah menjejaskan kesahan penyampaian tersebut. 
Sekiranya saman tersebut tidak dapat disempurnakan dengan cara penyampaian ke diri defendan atau peguam syarie defendan, dalam keadaan tertentu mahkamah boleh mengeluarkan perintah untuk penyampaian ganti setelah mahkamah berpuashati bahawa segala usaha yang munasabah telah dilakukan bagi menyempurnakan saman tersebut. Pihak plaintif perlu memfailkan notis permohonan penyampaian saman ganti dan ini akan mengambil masa yang lama untuk menunggu tarikh sebutan di hadapan pendaftar atau hakim. Berkaitan dengan hal ini seorang peguam syarie berpendapat seperti berikut:

\begin{abstract}
"Kelewatan yang paling ketara yang kita tak dapat dielakkan adalah di peringkat serahan saman. Ada dua kelewatan yang berlaku semasa serahan saman, iaitu jika tidak dapat diserah secara ke diri, maka urusan untuk proses penyampaian ganti itu akan mengambil masa dan jika serahan perlu dibuat di luar bidang kuasa dan keduanya kelewatan berlaku jika pertukaran hakim, perpindahan hakim dan menunggu hakim yang baru dan juga urusan-urusan lain yang tidak dapat dielakkan sama ada hakim atau peguam itu sendiri." R11 I-14/06
\end{abstract}

\title{
Kategori Pengurusan Kes
}

Semasa penulis menjalankan pemerhatian, tatacara pengurusan kes belum digubal dalam arahan amalan. Arahan amalan no. 7 tahun 2016 mula dikuatkuasakan pada 9 Disember 2016. Melalui pemerhatian penulis, proses interlokutori bantahan awal mengambil masa selama empat bulan untuk diselesaikan. Selain itu, penulis mendapati masa yang diambil untuk menyelesaikan pliding masing-masing mengambil masa lebih kurang satu tahun untuk pihak-pihak menyelesaikan pliding. Berdasarkan pada pemerhatian penulis, isu interlokutori boleh diselesaikan dalam tempoh masa dua bulan sahaja. Ini kerana ia melibatkan pendengaran ringkas yang hanya berdasarkan kepada afidavit dan penghujahan sahaja dan tidak memerlukan keterangan yang panjang. Sebagai contoh, tiga responden bersetuju pengurusan kes yang tidak sistematik menjadi punca kepada kelewatan kes fasakh.

“....adakalanya kes lambat dari segi prosedur pengurusan kes.” R7 I-22/05

“...apabila tiada peguam dia tidak faham proses jadi mungkin kat situ dia akan lambat kes bila mahkamah terpaksa tangguhkan kes bila defendan tak bersedia." R4 I-05/15 
"Kalau seseorang tak ambil peguam dan tak tahu nak buat apa, kes akan jadi lewat. Tapi kalau ada peguam pula, mungkin lambat serah dokumen kepada defendan atau lambat failkan afidavit penyampaian, dah tangguh tarikh. Jadi benda-benda macam ni kena on time." R9 I-06/16

\section{Sub tema 2: Peringkat Perbicaraan}

Terdapat dua kategori di bawah sub tema peringkat perbicaraan iaitu kaedah memberikan keterangan dan tempoh masa perbicaraan. Dapatan ini dijelaskan secara mendalam seperti di bawah.

\section{Kategori Kaedah Memberikan Keterangan}

Sewaktu pengendalian kes fasakh, jika persetujuan dicapai sama ada suami isteri setuju bercerai atau mereka berbaik-baik semula, ianya perlu ditarik semula dan kes ditutup. Ini kerana tuntutan fasakh adalah bertujuan untuk mendapatkan perintah daripada hakim bagi membubarkan perkahwinan yang tidak dipersetujui oleh suami mahupun isteri berdasarkan alasan-alasan yang memuaskan hati mahkamah dalam keadaan salah satu pihak tidak bersetuju dengan tuntutan pihak yang satu lagi.

Di Malaysia, kaedah pendengaran kes fasakh adalah sama dengan kes-kes mal yang lain di mana Enakmen Tatacara Mal memperuntukkan bahawa semua prosiding yang dimulakan dengan saman hendaklah didengar dan diputuskan di dalam mahkamah terbuka. Manakala pihak-pihak pula boleh hadir sendiri atau melalui peguam syarienya. Jika diteliti kepada peruntukan-peruntukan di atas, proses dan prosedur perbicaraan sebagaimana yang ditetapkan oleh undang-undang adalah untuk mempercepatkan proses perbicaraan kes. Pihak plaintif diberikan hak untuk meneruskan perbicaraan jika pihak yang satu lagi sengaja tidak menghadirkan diri ke mahkamah atau memohon penangguhan tanpa sebab yang munasabah. Begitu juga pihak defendan akan mendapat keadilan bagi menutup kes ke atasnya jika pihak plaintif tidak hadir sewaktu perbicaraan ditetapkan tanpa sebab-sebab yang munasabah.

Proses memberi keterangan amat penting untuk mengeluarkan keseluruhan pernyataan mahupun pembelaan berserta dengan pembuktian di hadapan hakim bicara. Dalam situasi di mana semua pihak hadir, suatu perbicaraan penuh akan dijalankan di mana plaintif hendaklah memulakan dengan membuka kesnya dan memberikan keterangan sebagaimana peruntukan Seksyen 126 Enakmen 
Tatacara Mal Mahkamah Syariah Selangor Tahun 2003. ${ }^{28}$ Sebagaimana yang telah ditetapkan oleh undang-undang tatacara mal, kaedah memberikan keterangan merangkumi tiga peringkat iaitu keterangan utama, soal balas dan keterangan semula.

Dari segi praktikal dan amalannya, apabila plaintif selesai memberikan keterangannya, hakim hendaklah memanggil defendan untuk mengemukakan keterangan bagi menjawab tuntutan plaintif. Keseluruhan keterangan pihakpihak akan direkodkan oleh mahkamah. Setelah keseluruhan keterangan termasuk saksi selesai, maka pihak-pihak hendaklah memasukkan penghujahan menutup kes tersebut berdasarkan kepada arahan mahkamah. Selagi mana prosiding kes belum selesai, mahkamah boleh memanggil mana-mana pihak untuk mengemukakan keterangan dan boleh membuat pemeriksaan semula pada semua bahan-bahan bukti yang dikemukakan dalam perbicaraan yang lalu.

Berdasarkan pemerhatian penulis dalam kes pertama, sesi keterangan memakan masa selama dua tahun satu bulan disebabkan kedua-dua pihak memberikan keterangan yang panjang dan pembuktian yang berbentuk dokumentasi yang banyak. Walaupun pihak plaintif dan defendan telah menyediakan afidavit (keterangan bertulis) masing-masing untuk meringkaskan perbicaraan, namun begitu sesi pemeriksaan balas telah memakan masa yang lama daripada pihak oponen masing-masing. Manakala dalam kes kedua, penulis mendapati masa yang diambil untuk sesi memberi keterangan adalah selama tiga tahun enam bulan disebabkan timbulnya dua permohonan interlokutori semakan sewaktu proses pendengaran keterangan plaintif. Terdapat responden menyifatkan keterangan secara lisan melambatkan dan memanjangkan proses perbicaraan kes fasakh:

“...menjadi masalah sebab proses perbicaraan itu hendaklah dalam keadaan lisan sebab lambat dan tak cukup keterangan." R3 I-25/04

\section{"Biasanya kalau bicara secara lisan, keterangan pihak-pihak sampai habis sampai dua tiga kali tarikh dan ada kala disebabkan kursus dan ada tangguhan-tangguhan di saat-saat terakhir..." $R 7$ I-22/05}

Selain itu, proses memberikan keterangan juga menyebabkan kes fasakh mengambil masa yang panjang, lebih-lebih lagi apabila melibatkan tuntutan balas nusyuz. Beberapa responden turut mengakui bahawa tuntutan balas sabitan nusyuz akan melambatkan prosiding perbicaraan kes fasakh.

28 Seksyen 126, Enakmen Tatacara Mal Mahkamah Syariah Negeri Selangor Tahun 2003. 
"Bagisaya sabitan nusyuzjuga menjadifaktoruntuk menyebabkan kes fasakh itu lambat diputuskan kerana mahkamah perlu bicarakan juga isu tentang nusyuz. Jadi akan mengambil masa jika dua isu untuk dibicarakan iaitu fasakh dan juga nusyuz. " R4 I-03/05

"Tuntutan balas nusyuz juga akan sedikit sebanyak mengganggu proses perbicaraan fasakh dan memberi kesan kepada kelewatan perbicaraan itu selesai. " R8 I-04/06

\section{Kategori Tempoh Masa Urusan Perbicaraan}

Penulis mendapati bahawa tempoh perbicaraan adalah merupakan tempoh yang begitu kritikal dan seringkali mengambil masa yang lama untuk diselesaikan. Keadaan ini berlaku antara lain disebabkan ketiadaan peruntukan undang-undang yang menetapkan tempoh masa untuk mengawal perbicaraan. Berdasarkan kepada permerhatian penulis terhadap prosiding kedua-dua kes di Mahkamah Syariah, jelas terdapat kelewatan perjalanan prosiding, di mana kes pertama dan kedua masing-masing memakan masa selama lima tahun dan empat tahun setengah. Tempoh masa perbicaraan untuk kes di Mahkamah Syariah tidak ditetapkan di dalam mana-mana peruntukan atau arahan amalan telah menjadi kekangan kepada kelancaran perbicaraan kes. Hal ini telah menyebabkan berlakunya kelewatan perbicaraan kes fasakh.

"...tangguhan dari pihak mahkamah yang masa yang tak lapang, tarikh dah tetap tapi hakim bicara ada kursus, mahkamah tak dapat bersidang." R5 I-07/05

"Masalah kita banyak pada kekangan masa kerana Mahkamah Syariah banyak kes. Kadang-kadang kalau bicara hanya sempat buat satu perkara dalam satu tempoh yang diberikan sebab mahkamah pun ada kes lain untuk didengar. Kadang-kadang kita dapat masa yang singkat untuk jalankan perbicaraan tak sempat nak habis. " R6 I-16/05

Ini juga termasuklah ketetapan bagi menyelesaikan pengemukaan dokumen dan permohonan interlokutori. Pemerhatian kes pertama menunjukkan mahkamah mengambil masa selama satu bulan untuk membuat keputusan daripada tarikh penggulungan hujah dimasukkan oleh pihak-pihak secara serentak manakala bagi kes kedua pula, penulis mendapati terdapat kes interlokutori yang memakan masa selama 1 tahun 1 bulan. Beberapa responden bersetuju mengenai isu interlokutori dan permohonan semakan menjadi faktor 
yang menyumbangkan kepada penangguhan perjalanan kes fasakh seperti perbualan di bawah:

"Ia bergantung kepada hakim sebab sekiranya peguam membantah pun bagi saya bila mahkamah benarkan interlokutori masih berjalan itu akan menyebabkan kelewatan. ” R8 I-04/06

"Isu interlokutori adalah salah satu punca kes fasakh ini lambat diselesaikan. Bila ada satu semakan bantahan awal ia juga akan menyebabkan kepada kelewatan kes dan apabila ada semakan dan sebagainya, kes induk, kes asal iaitu fasakh akan tergantung apabila diputuskan kes bantahan atau semakan." R4 I-03/05

Selain itu, ikatan dokumen yang terlalu banyak serta menyebabkan perbicaraan menjadi panjang.

"Perbicaraan yang panjang apabila ada dokumen-dokumen yang banyak dan juga kadang-kadang tangguhan demi tangguhan mungkin pihak-pihak tak bersedia atau tak dapat hadirkan juga tangguhan dari pihak mahkamah yang masa yang tak lapang, tarikh dah tetap tapi hakim bicara ada kursus, mahkamah tak dapat bersidang jadi tangguhan-tangguhan yang macam itu la". R5 I-07/05

"Dokumentasi yang banyak dan tidak relevan sangat juga menyebabkan masalah...Semasa perbicaraan tidak boleh berjalan secara lancar disebabkan masalah yang saya sebut tadi iaitu dokumentasi. " R8 I-04/06

\section{Sub tema 3: Peringkat Pasca Perbicaraan}

Terdapat dua kategori di bawah sub tema peringkat perbicaraan iaitu penetapan tempoh masa dan alasan penghakiman serta penggantungan pelaksanaan perintah. Perkara ini dijelaskan secara mendalam seperti di bawah.

\section{Kategori Tempoh Masa Urusan Rayuan}

Sebagaimana yang dijelaskan sebelum ini, undang-undang memberikan hak kepada pihak-pihak yang tidak berpuas hati dengan keputusan hakim untuk merayu ke mahkamah yang lebih tinggi. Oleh kerana pihak-pihak telah melalui proses yang panjang sewaktu perbicaraan, maka sepatutnya proses rayuan dapat diselesaikan dengan lebih cepat kerana tidak memerlukan keterangan 
diambil semula daripada pihak-pihak sebagaimana perbicaraan awal. Malah, ia lebih kepada meneliti dokumen-dokumen yang dikemukakan di dalam perbicaraan yang lalu.

Jika diperhatikan kepada prosedur yang sedia ada, penulis mendapati bahawa proses penyediaan rekod rayuan yang memperuntukkan masa selama enam minggu dari tarikh notis keterangan disiapkan tidak menyebabkan kelewatan. Namun begitu, terdapat perkara penting yang ketinggalan dalam soal penetapan tempoh masa iaitu penyediaan dan pengeluaran nota keterangan dan alasan penghakiman oleh hakim bicara. Selain itu, penyampaian notis rayuan turut menjadi punca kelewatan pada peringkat rayuan.

Berdasarkan kepada pemerhatian, penulis mendapati mahkamah mengambil masa selama lima bulan (22 Disember 2015 hingga 24 Mei 2017) untuk mengeluarkan notis bahawa salinan diperakui bagi nota keterangan dan penghakiman sudah siap. Sedangkan penulis mendapati bahawa kesemua arahan mahkamah dipatuhi oleh kedua-dua pihak mengenai penetapan tarikh pemfailan kertas-kertas kausa dan dokumen sehinggalah ke peringkat penghujahan yang jelas menunjukkan tiada sebarang kelengahan yang tidak wajar berlaku. Secara keseluruhannya bermula dari tarikh pemfailan notis sehingga keputusan dikeluarkan, kes rayuan ini memakan masa selama setahun satu bulan. Beberapa responden juga turut berpendapat bahawa alasan penghakiman menjadi salah satu kekangan pada peringkat pasca perbicaraan.

“...kelewatan pada alasan penghakiman...mahkamah menyediakan alasan penghakiman sebab sekarang tidak ada time frame. " R6 I-16/05

"Biasanya kelambatan untuk kes rayuan disebabkan penyediaan alasan penghakiman di peringkat mahkamah rendah. " R8 I-04/06

Selain itu, penyampaian notis rayuan turut menjadi punca kelewatan pada peringkat rayuan seperti mana berikut:

"Bagi sayalah tempoh masa penyampaian notis rayuan kepada responden tak boleh disamakan dengan tempoh masa pemfailan notis rayuan ke mahkamah. Sepatutnya tempoh masa penyampaian kepada responden dilanjutkan dalam 30 hari." $R 3$ I-25/04

"Peguam seringkali menghadapi masalah untuk menyerah sampaikan notis rayuan terutama apabila responden cuba mengelakkan diri daripada notis tersebut sedangkan masa yang diberikan adalah singkat." R9 I-06/06 


\section{Kategori Penggantungan Pelaksanaan Perintah}

Pada masa ini undang-undang tatacara mal memperuntukkan bahawa pemfailan notis rayuan tidak secara automatik menggantung pelaksanaan perintah tetapi ianya perlu dipohon oleh pihak perayu secara berasingan dengan mengemukakan alasan-alasan yang menyokong kepada permohonan penggantungan tersebut. Permohonan tersebut telah menyebabkan pihak responden sekali lagi diheret ke mahkamah untuk menyatakan pendiriannya sama ada menerima atau membantah permohonan pemohon. Situasi tersebut dapat dielakkan sekiranya suatu ketetapan dibuat sama ada pemfailan notis rayuan secara automatik menggantung pelaksanaan perintah fasakh ataupun tidak membenarkan sama sekali rayuan terhadap kes fasakh difailkan. Sesetengah responden berpendapat seperti berikut:

"Kalau ada rayuan difailkan, sepatutnya tidak perlu permohonan penggantungan pelaksanaan perintah kerana peruntukan yang dinyatakan sekarang pun hanya memerlukan kita membuktikan notis rayuan telah difailkan sudah mencukupi dan tidak perlu melibatkan permohonan interparte." R6 I-16/05

"Dalam kes fasakh, penggantungan amat penting dibenarkan sebaik sahaja rayuan difailkan kerana jika penggantungan tak dibuat, pihak isteri akan mendaftarkan perceraian dan Pejabat Agama akan keluarkan surat cerai. Jika rayuan suami dibenarkan akan menjadi konfliklah terutama apabila isteri dah berkahwin lain menggunakan surai cerai tersebut." R11 I-14/06

\section{Tema 2: Cadangan untuk Penambahbaikan Prosedur Fasakh}

Rajah berikut menunjukkan peta konsep cadangan-cadangan penambahbaikan prosedur kes fasakh bagi menjawab objektif kajian yang kedua, iaitu menganalisis peruntukan dalam undang-undang tatacara mal bersabit dengan tuntutan fasakh. 
Rajah 3: Peta Konsep Tema Cadangan-Cadangan Penambahbaikan Prosedur Kes Fasakh

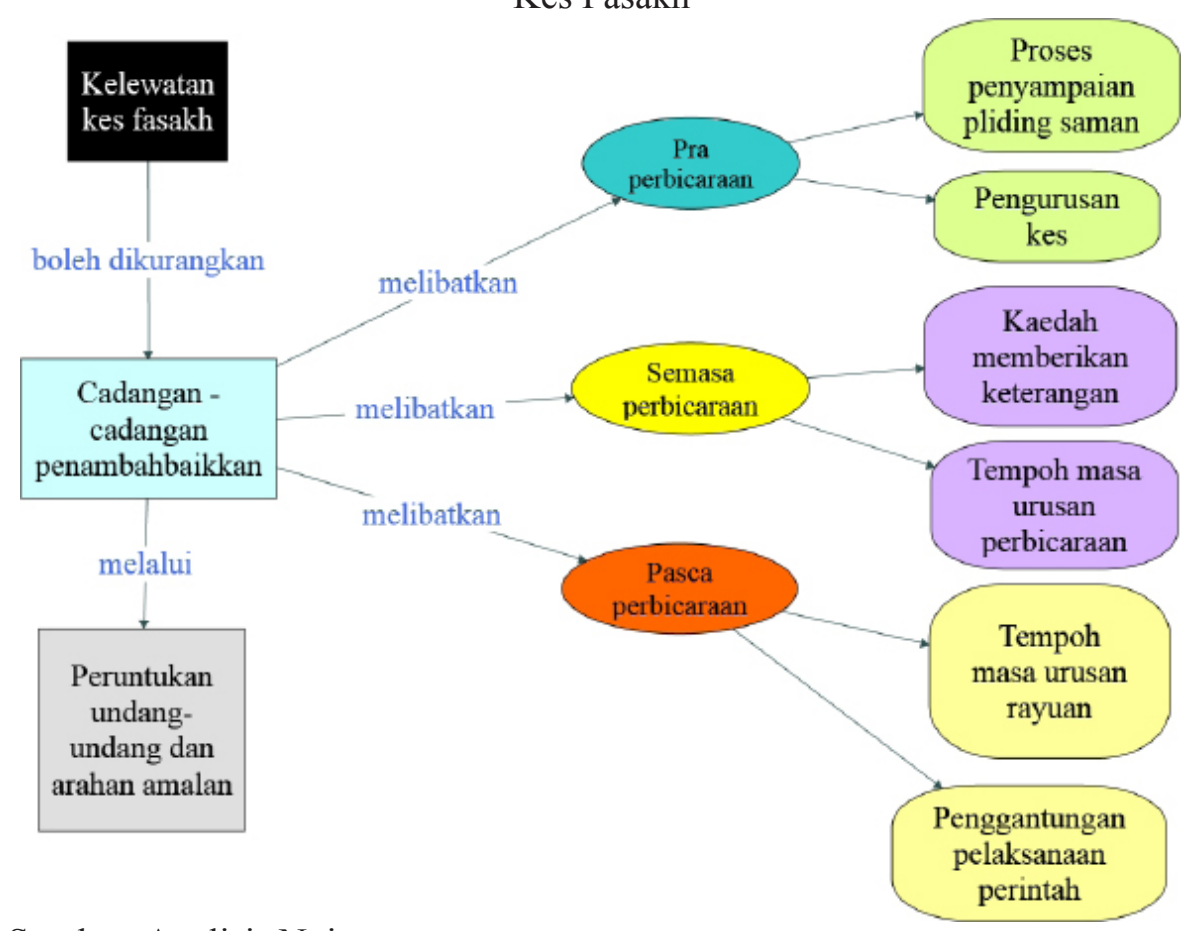

Sumber: Analisis Nvivo

\section{Sub tema 1: Peringkat Pra Perbicaraan}

Terdapat dua kategori di bawah sub tema peringkat pra perbicaraan iaitu proses penyampaian pliding saman dan pengurusan kes. Perkara ini dijelaskan secara mendalam seperti di bawah.

\section{Kategori Proses Penyampaian Pliding Saman}

Penyampaian saman adalah suatu kaedah yang ditetapkan oleh undangundang sebagai satu cara untuk menghadirkan defendan. Oleh itu, kegagalan untuk mematuhi Seksyen 121 (1) (b) yang dibaca bersama Seksyen 41 dan Subseksyen 48 (1) (2) Enakmen 4 Tahun 2003 ini boleh menyebabkan prosiding perbicaraan yang dijalankan dikira sebagai tidak sah dan terbatal. Manakala perintah penyampaian ganti secara pos berdaftar dan juga tampalan di alamat di mana defendan berada akan dapat mempercepatkan proses penyampaian kepada defendan yang sukar dihubungi secara ke diri. Walau bagaimanapun, 
proses penyampaian saman mengambil masa yang lama berikutan keengganan pihak defendan untuk menerima saman. Lantaran itu, terdapat responden yang berpendapat penyampaian saman secara ke diri menyebabkan masa yang panjang.

Beberapa cadangan penambahbaikan dalam proses penyampaian saman turut diberikan oleh responden-responden seperti mahkamah membenarkan penyerahan dibuat dengan menggunakan media baru (internet) sama ada secara emel atau platform lain. Selain itu, proses penyerahan saman boleh dipercepatkan tanpa perlu perintah penyampian di luar bidang kuasa bagi defendan yang berada di dalam Malaysia.

\section{Kategori Pengurusan Kes}

Pengurusan kes adalah kunci kepada kelancaran perbicaraan. Namun begitu, undang-undang tatacara mal setakat ini tidak memperuntukkan kaedah khusus bagi menjalankan pengurusan kes. Oleh sebab itu, penulis mendapati Mahkamah Syariah di setiap negeri telah mewujudkan arahan amalan masingmasing ataupun menggunapakai amalan yang dikeluarkan oleh JKSM bagi melicinkan proses pengurusan kes sebelum kes didengar dan dibicarakan di hadapan hakim. Namun begitu, terdapat banyak cadangan daripada responden yang boleh dipertimbangkan untuk ditambahbaikan proses pengurusan kes di Mahkamah Syariah. Antara lain mereka menyatakan pengurusan kes atau sebutan kes boleh dibuat di hadapan pendaftar atau jika perlu pengurusan dibuat di hadapan hakim dengan terus membuat siasatan awal dan sekiranya hakim mendapati ada pengakuan atas dakwaan itu, maka hakim boleh terus memfasakhkan pernikahan.

Terdapat beberapa responden yang mencadangkan kes fasakh perlu juga melalui majlis sulh supaya pihak-pihak dapat berbincang dan mengenal pasti masalah-masalah yang sedang dihadapi oleh mereka. Di mana perkara-perkara yang mengaibkan dapat dihindari daripada terdedah kepada umum sewaktu perbicaraan jika mereka dapat berlapang dada menerima hakikat sebenar kedudukan permasalahan rumah tangga mereka.

Walau bagaimanapun, beberapa responden tidak bersetuju dengan pelaksanaan majlis sulh kerana antara lain berpendapat bahawa ianya telah difahami oleh pasangan dan proses ini hanya akan memperbanyakkan lagi prosedur dan kerenah birokrasi. 


\section{Sub tema 2: Peringkat Perbicaraan}

Terdapat dua kategori di bawah sub tema peringkat perbicaraan iaitu kaedah memberikan keterangan dan tempoh masa perbicaraan. Dapatan ini dijelaskan secara mendalam seperti di bawah.

\section{Kategori Kaedah Memberikan Keterangan}

Penulis berpendapat kaedah perbicaraan kes fasakh berasaskan kepada pliding saman dan pernyataan tuntutan ini mengambil masa yang panjang untuk diselesaikan. Ini kerana berdasarkan kepada Undang-undang Tatacara Mal, kedua-dua kaedah pemfailan kes mempunyai kesan yang berbeza. Di mana kesan kepada sesuatu permohonan yang dibuat melalui notis dan afidavit tidak memerlukan kepada keterangan semula tetapi memadai dengan fakta-fakta yang telah diikrarkan berserta dengan ekshibit-ekshibit yang dikemukakan bersama dengan afidavit tersebut untuk mahkamah menimbangkan sesuatu keputusan. Pendengaran kes melalui kaedah ini akan mempercepatkan perjalanan kes dan memudahkan hakim bicara memutuskan kes di hadapannya.

Manakala permohonan secara saman dan pernyataan tuntutan bukanlah satu bentuk keterangan yang boleh diterima pakai tanpa keterangan bersumpah pihak plaintif di hadapan mahkamah. Maka permohonan yang difailkan melalui saman haruslah melalui proses perbicaraan yang panjang untuk mendapatkan semula keterangan pihak-pihak yang terlibat dalam kes tersebut.

Berdasarkan kepada peruntukan yang sedia ada, proses tersebut akan melalui beberapa peringkat perbicaraan iaitu keterangan utama, soal balas, keterangan semula dan pengemukaan dokumen serta saksi-saksi. Keseluruhan tempoh masa yang biasa diambil untuk menyelesaikan perbicaraan adalah antara satu ke dua tahun berasaskan kepada masa penangguhan antara satu ke dua bulan bagi setiap sesi pendengaran.

Berbanding dengan kaedah notis permohonan dan afidavit, mahkamah pada dasarnya boleh memutuskan kes fasakh berdasarkan kepada proses pendengaran yang ringkas dengan meneliti kepada fakta-fakta dan buktibukti yang telah diangkat sumpah oleh pihak-pihak melalui afidavit masingmasing. Melalui kaedah ini, masa yang diperlukan oleh mahkamah hanyalah empat sesi pendengaran sahaja iaitu sebutan, pengemukaan afidavit jawapan pihak responden, pengemukaan afidavit jawapan balas pihak pemohon dan penghujahan. Dengan demikian, masa perbicaraan kes dapat disingkatkan kepada empat bulan sahaja berasaskan kepada penangguhan dua minggu ke tiga minggu bagi setiap sesi pendengaran. 
Merujuk kepada isu pemfailan kes nusyuz serentak dengan kes fasakh, responden berpendapat bahawa perbicaraan kes fasakh dan nusyuz hendaklah dirangkumkan dan dibicarakan sekali walaupun permohonan nusyuz telah difailkan terlebih dahulu berbanding fasakh.

\section{Kategori Tempoh Masa Urusan Perbicaraan}

Tempoh masa perbicaraan adalah begitu kritikal kepada setiap pihak yang terlibat dalam setiap perbicaraan kes. Sebagaimana yang didapati daripada penelitian kes, tempoh masa perbicaraan adalah yang paling lama diambil oleh mahkamah berbanding dengan tempoh masa di peringkat-peringkat yang lain. Walaupun terdapat peruntukan undang-undang yang memberikan hak kepada hakim untuk menentukan kaedah perjalanan sesuatu kes, tetapi tidak terdapat satu peruntukan yang mengehadkan tempoh masa perbicaraan sesuatu kes wajar diselesaikan. Oleh yang demikian, penulis telah mendapatkan pandangan daripada responden-responden yang antara lain menyatakan bahawa mereka merasakan perlu ketegasan di pihak mahkamah khususnya dalam situasi pihak-pihak tidak hadir sewaktu pendengaran kes. Ada juga yang berpendapat bahawa penetapan tarikh dibuat secara marathon sekurang-kurangnya tiga hari berturut-turut.

\section{Sub tema 3: Peringkat Pasca Perbicaraan}

Terdapat dua kategori di bawah sub tema peringkat perbicaraan iaitu penetapan tempoh masa dan alasan penghakiman serta penggantungan pelaksanaan perintah. Perkara ini dijelaskan secara mendalam seperti di bawah.

\section{Kategori Tempoh Masa Urusan Rayuan}

Hak untuk merayu wajar diberikan kepada mana-mana pihak yang tidak berpuas hati dan terkilan dengan keputusan yang diberikan oleh hakim bicara berdasarkan Seksyen 139, Enakmen 4 Tahun 2003. Secara praktikalnya, proses rayuan juga akan mengambil masa yang lama dan lebih memeritkan bagi kaum wanita apabila pihak suami memohon penggantungan perlaksanaan perintah fasakh. ${ }^{29}$ Peruntukan dan arahan amalan tersebut akan menyebabkan pihak isteri terpaksa menunggu tempoh yang lebih lama sementara perbicaraan

29 Seksyen 144 Enakmen Tatacara Mal Mahkamah Syariah Negeri Selangor Tahun 2003 menyebut: Pemfailan suatu notis rayuan tidaklah berkuat kuasa sebagai penggantungan pelaksanaan, tetapi mahkamah boleh, atas permohonan dan apabila sebab yang mencukupi ditunjukkan, menggantung pelaksanaan atas apaapa terma sebagaimana yang difikirkannya patut. 
rayuan diselesaikan. Namun dari satu sudut yang lain jika penggantungan ini tidak dibenarkan dan rayuan tersebut memihak kepada pihak suami, maka jika isteri telah berkahwin lain, perkahwinan keduanya itu terpaksa dibubarkan. Keadaan ini sudah pasti akan mendatangkan kesulitan yang lebih besar jika isteri telah mengandung sedangkan perkahwinan beliau terpaksa dibubarkan.

Peringkat pasca perbicaraan atau proses rayuan sering kali menjadi faktor kelewatan kes fasakh sedangkan keputusan telah dikeluarkan oleh pihak mahkamah. Namun begitu, terdapat beberapa responden yang berpendapat proses rayuan tidak perlu dilakukan dalam kes fasakh dan cukup dengan sabitan satu peringkat mahkamah sahaja sama ada di mahkamah rendah yang diamalkan sekarang ataupun kes tersebut terus dibicarakan di mahkamah tinggi.

Jika proses rayuan perlu diteruskan, terdapat cadangan supaya pindaan peruntukan Undang-undang Tatacara Mal mengenai tempoh masa bagi pihak hakim bicara mengeluarkan alasan penghakiman dan catatan perbicaraan hendaklah dibuat. Ini adalah perlu supaya tiada lagi ruang yang menjadi punca kepada kelewatan proses rayuan. Berdasarkan maklumbalas responden, kelewatan proses rayuan adalah disebabkan hakim mengambil masa yang panjang untuk mengeluarkan alasan penghakiman dan catatan perbicaraan sehingga ada responden yang menerima dokumen tersebut selepas tiga tahun notis rayuan difailkan.

\section{Kategori Penggantungan Pelaksanaan Perintah}

Antara masalah yang wujud apabila sesuatu kes fasakh dirayu, berkemungkinan pihak plaintif (isteri) yang telah mendapat perintah fasakh akan berkahwin lain walaupun beliau mengetahui adanya rayuan daripada pihak defendan (suami) telah difailkan. Perkara ini terjadi apabila mahkamah mengeluarkan perintah sabitan fasakh dan perintah tersebut didaftarkan di pejabat agama untuk mengeluarkan sijil perceraian. Apabila permohonan penggantungan perintah perlu dibuat secara interlokutori oleh pihak suami, ia akan mengambil masa yang agak lama sehingga menyebabkan tempoh iddah isteri selesai dan tiada halangan lagi di pihak isteri untuk berkahwin lain. Masalah akan timbul sekiranya rayuan pihak suami dibenarkan oleh pihak mahkamah dan perintah fasakh kemudiannya dibatalkan. Dalam hal ini, penulis telah mendapatkan pandangan responden yang berpendapat bahawa bagi mengatasi masalah ini secara automatik hendaklah dikuatkuasakan atau diperuntukkan setelah adanya rayuan difailkan bagi mengelakkan timbul persoalan hukum syarak di kemudian hari. 


\section{DAPATAN KAJIAN}

Di Selangor, kesedaran mengenai kelewatan pengendalian kes fasakh ini telah diatasi dengan mengadakan alternatif perceraian secara hakam. Peruntukan berkenaan dengan perceraian melalui perlantikan hakam telah dilaksanakan melalui penggubalan Kaedah-Kaedah Hakam (Negeri Selangor) 2014. Melalui peruntukan ini mahkamah diberikan bidang kuasa untuk melantik Hakam dalam kalangan mereka yang berkelayakan dan memenuhi syarat yang ditetapkan oleh undang-undang. Namun begitu, Hakam yang dilantik perlu terlebih dahulu mendapatkan perwakilan daripada prinsipal untuk bertindak sehingga ke tahap boleh menceraikan pihak isteri sekiranya Majlis Tahkim yang dijalankan masih mendapati shiqaq antara suami dan isteri masih berterusan dan tidak dapat didamaikan. Namun begitu, berdasarkan kepada realiti yang berlaku di Selangor dengan jumlah penduduk yang ramai serta kawasan yang luas, maka isu penyampaian saman kepada pihak suami seringkali menjadi masalah sehingga mahkamah tidak dapat meneruskan kes tuntutan perceraian disebabkan pembentukan Jawatankuasa Pendamai (JKP) sebelum proses pelantikan Hakam tidak dapat disempurnakan. Oleh yang demikian, tuntutan fasakh masih menjadi relevan untuk diteruskan dengan penambahbaikan undang-undang prosedur agar tidak berlaku penganiayaan terhadap kaum wanita. Sehubungan dengan itu, beberapa cadangan dan saranan dikemukakan untuk menambahbaik peruntukan undang-undang khususnya berkaitan dengan proses dan prosedur tuntutan fasakh di Selangor.

\section{Mewujudkan Dewan Bicara Khas Kes Fasakh}

Mahkamah Khas yang dimaksudkan ialah dewan bicara yang khusus untuk mendengar kes fasakh dan perbicaraan diadakan secara berterusan dalam masa tiga hari berturut-turut supaya tuntutan-tuntutan tersebut dapat diselesaikan dengan cepat dan efisien berbanding sekarang tuntutan fasakh mengambil masa sehingga tiga tahun berdasarkan prosedur yang sedia ada. Perkara ini boleh dilaksanakan dengan arahan atau pekeliling ketua hakim ataupun Jabatan Kehakiman Syariah Malaysia (JKSM).

\section{Meringkaskan Proses Penyampaian}

Berdasarkan kepada peruntukan yang sedia ada, proses penyampaian terpaksa melalui beberapa peringkat sekiranya saman atau dokumen tidak dapat diserahkan secara ke diri pihak defendan. Keadaan ini menyebabkan berlaku banyak penangguhan kes semata-mata untuk memenuhi prosedur 
penyampaian. Sedangkan, proses penyampaian hendaklah disifatkan telah disampaikan apabila saman atau dokumen tersebut telah diserahkan di alamat pihak defendan dan penyampaian tersebut dibuktikan secara nyata dan jelas melalui afidavit penyampaian. Oleh yang demikian, penulis mencadangkan peruntukan Seksyen 41 Enakmen 4 Tahun 2003 dipinda selari dengan perkembagan terkini teknologi maklumat dengan memasukkan peruntukan penyampaian melalui email juga hendaklah dikira sebagai penyampaian yang sempurna seumpama penyampaian ke diri. Cadangan peruntukan pindaan adalah sebagaimana berikut:

\section{Seksyen 41. Cara penyampaian}

(4) Penyampaian sesuatu saman atau dokumen lain secara e-mel rasmi hendaklah disifatkan sebagai penyerahan ke diri kepada orang yang kepadanya saman atau dokumen itu hendak disampaikan.

\section{Keterangan secara Afidavit}

Proses memberikan keterangan berdasarkan peruntukan yang sedia telah memakan masa yang panjang terutamanya sewaktu sesi keterangan utama sehingga melibatkan beberapa penangguhan untuk menyempurnakannya. Bagi mempercepatkan proses keterangan utama pihak-pihak, ia hendaklah dibuat secara afidavit dan pihak-pihak hendaklah melengkapkan keterangan dan ikatan dokumen dalam tempoh masa 14 hari dari tarikh perbicaraan ditetapkan. Dalam masa yang sama juga hendaklah diserahkan kepada pihak satu lagi untuk persediaan soal balas pada tarikh seterusnya. Kaedah ini boleh dilaksanakan dengan meminda peruntukan Seksyen 101 Enakmen 4 Tahun 2003 sebagaimana berikut:

\section{Seksyen 101: Keterangan melalui afidavit}

Mahkamah boleh pada masa atau sebelum perbicaraan apaapa prosiding memerintahan supaya afidavit mana-mana pihak dan saksinya dibacakan pada perbicaraan itu jika dalam hal keadaaan kes itu adalah difikirkannya munasabah untuk memerintahkan sedemikian.

\section{Mengadakan Siasatan Awal untuk Mengenal pasti Penyelesaian Segera}

Proses ini bagi mengenal pasti tuntutan yang tidak jelas alasan fasakh yang dikemukakan atau tidak mencukupi bukti tetapi diakui oleh suami bahawa 
rumah tangga mereka menghadapi syiqaq perkahwinan yang berpanjangan. Proses ini juga adalah untuk mengenal pasti kemungkinan tuntutan fasakh boleh diubah kepada perceraian melalui persetujuan bersama atau pihakpihak untuk memulihkan hubungan perkahwinan mereka dan membatalkan tuntutan di Mahkamah. Malah melalui proses pra perbicaraan juga, hakim boleh mengenal pasti sama ada terdapat sebarang pengakuan oleh pihak suami ke atas mana-mana pertuduhan atau alasan yang dikemukakan oleh isteri dan mahkamah boleh mensabitkan fasakh berdasarkan kepada pengakuan suami tanpa proses perbicaraan yang penuh. Untuk tujuan tersebut, penulis mencadangkan supaya peruntukan Seksyen 126 Enakmen 4 Tahun 2003 dipinda sebagaimana berikut:

\section{Seksyen 126: Susunan ucapan}

(c) Mahkamah boleh mengadakan siasatan awal ke atas keterangan dan dokumen pihak-pihak melalui pliding masingmasing dan boleh memutuskan kes setelah berpuas hati dengan siasatan tersebut.

\section{Mewajibkan Pengurusan Kes dan Perbicaraan Dibuat secara Berterusan dengan Ketetapan Masa bagi Setiap Sesi}

Perbicaraan tuntutan fasakh hendaklah dibuat secara berterusan atau marathon sehingga selesai tanpa adanya penangguhan untuk tempoh masa yang lama. Dalam tempoh masa yang ditetapkan tersebut, pihak-pihak hendaklah bersedia tanpa sebarang alasan untuk menangguhkan prosiding atau alasan-alasan yang remeh dan bersifat mendaftar. Untuk tujuan tersebut, penulis mencadangkan suatu pindaan dibuat pada peruntukan Seksyen 119 (A) Enakmen 4 Tahun 2003 sebagaimana berikut:

\section{Seksyen 119 (A): Pendengaran di dalam mahkamah}

Bagi maksud peruntukan seksyen di atas, sesuatu kes hendaklah didengar dan diselesaikan dalam tempoh kurang daripada 3 bulan dari tarikh pemfailan kes.

\section{Tidak Membenarkan Kes Nusyuz Berjalan Serentak dengan Kes Fasakh}

Berdasarkan prosedur yang diamalkan sekarang, tuntutan balas nusyuz boleh difailkan dalam kes fasakh sehingga menyebabkan perbicaraan kes menjadi panjang dan meleret-leret apabila hakim bicara mendengar bersama faktafakta berkaitan dengan tuntutan balas tersebut. Tuntutan nusyuz hendaklah 
dibuat secara berasingan dan tidak boleh dicampuradukkan dalam tuntutan fasakh kerana ia mempunyai kesan yang berbeza dan perbicaraan kes fasakh tidak wajar menunggu keputusan sama ada seseorang isteri tersebut disabitkan nusyuz atau tidak. Lebih-lebih lagi apabila pihak isteri tidak hanya mengemukakan alasan kegagalan suami memberikan nafkah. Untuk melaksanakan amalan ini, penulis mencadangkan Ketua Hakim Syarie ataupun Jabatan Kehakiman Syariah Malaysia (JKSM) mengeluarkan arahan kepada Mahkamah Syariah seluruh Malaysia untuk tidak membenarkan kes nusyuz didengar serentak dengan kes fasakh.

\section{Permohonan Interlokutori dan Semakan Tidak Wajar Menggantung Perjalanan Kes Fasakh}

Permohonan interlokutori dan semakan kebiasaannya akan difailkan apabila salah satu pihak tidak berpuas hati dengan arahan ataupun ketetepan yang dibuat oleh hakim bicara sewaktu kes sedang berjalan. Kesan daripada pemfailan kes permohonan tersebut menyebabkan kes fasakh yang sedang berjalan ditangguhkan sementara menunggu keputusan semakan dikeluarkan oleh mahkamah yang lebih tinggi. Keadaan ini menyebabkan berlaku tangguhan kepada perjalanan prosiding kes fasakh dalam tempoh yang agak lama. Sehubungan dengan itu, penulis mencadangkan peruntukan undangundang pentadbiran agama Islam negeri-negeri dipinda sebagaimana berikut:

Seksyen 66: Bidang kuasa pengawasan dan penyemakan mahkamah tinggi syariah

(1) $\ldots$

(2) Kecuali melibatkan tuntutan fasakh, apabila mahkamah tinggi syariah memanggil rekod sesuatu perkara atau prosiding di bawah subsekyen 1, semua prosiding dalam mahkamah rendah syariah tentang perkara atau prosiding itu hendaklah digantung sementara menanti perintah selanjutnya daripada mahkamah tinggi syariah.

\section{Rayuan Hendaklah Diselesaikan dalam Tempoh 90 Hari}

Dalam kes rayuan fasakh pula, ia hendaklah diselesaikan selewat-lewatnya dalam tempoh 90 hari atau tiga bulan sahaja pada setiap peringkat mahkamah rayuan daripada tarikh notis rayuan difailkan berbanding tempoh sekarang sehingga mencecah 1 tahun dan lebih. Kebiasaan kelewatan adalah di 
peringkat mahkamah yang gagal menyediakan nota perbicaraan dan alasan penghakiman pada masa yang telah ditetapkan menerusi arahan amalan. Kepatuhan Hakim Bicara terhadap tempoh masa penyediaan nota keterangan dan alasan penghakiman hendaklah diberikan perhatian yang serius oleh pihak Ketua Hakim Syarie agar proses rayuan berjalan lancar. Oleh itu, arahan ini perlu dimasukkan ke dalam pindaan sebagaimana berikut:

Seksyen 147: Tempoh pendengaran rayuan

Kes rayuan hendaklah diselesaikan dalam tempoh kurang daripada 90 hari atau 3 bulan.

\section{KESIMPULAN}

Berdasarkan kepada dapatan kajian, adalah jelas bahawa permasalahan kelewatan kes fasakh sememangnya ada berkait dengan undang-undang tatacara mal. Walaupun ia melibatkan beberapa peruntukan sahaja seperti yang dibincangkan di atas, namun penulis dapat menunjukkan bahawa kesannya begitu ketara sekali kepada kelancaran perjalanan kes. Sehubungan dengan itu, cadangan dan saranan yang dikemukakan oleh penulis mengenai pindaan kepada peruntukan tertentu wajar diberikan perhatian serius dari pihak berwajib bagi memastikan permasalahan yang menjadi punca kepada kelewatan kes fasakh dapat ditangani dan diselesaikan dalam tempoh masa yang munasabah bagi mengelakkan penganiayaan terhadap pihak-pihak yang terlibat.

\section{RUJUKAN}

Auerbach Carl \& Louise B. Silverstein, Qualitative Data: An Introduction to Coding and Analysis (New York: NYU Press, 2003).

Chua Yan Piaw, Kaedah Penyelidikan (Kuala Lumpur: McGraw-Hill Education, 2014).

Crowe Sarah et al., 'The Case Study Approach,' BMC Research Medical Methodology, vol. 11/100 (2011): 1-9.

Farah Safura Muhammud dan Aminuddin Ruskam, 'A Review of Discrimination Against Women in Shariah Courts,' Sains Humanika, vol. 5/3 (2015): 9-14.

Greg Guest et al., 'Choosing Qualitative Data Analysis Software,' in Applied Thematic Analysis (Thousand Oaks, CA: Sage, 2012), 217-238.

Harun Din, al-Furqah bayn al-Zawjayn, li al-Mawāni 'al-Sharī'ah Fiqhan wa Qaḍā'an (Kuala Lumpur: Percetakan Waatan, 1984). 
John W. Creswell \& Dana L. Miller, 'Determining Validity in Qualitative Inquiry,' Theory into Practice Journal, vol. 39/3 (2000): 124-130.

Kenneth D. Bailey, Methods of Social Research. New York: Fee Press, 1978).

Md Zawawi Abu Bakar \& Wan Ab Rahman Khudzri Wan Abdullah, 'An Analysis on the Issues of the Rights of Spouses in the Islamic Family Law in Malaysia,' International Journal of Business and Social Research, vol. 1/1 (2011): 94-108.

Ain Husna Mohd Arshad, Roslina Che Soh@Yusoff, Najibah Mohd Zin, \& Nora Abdul Hak, 'Mediation Services at the Family Courts of Singapore and Australia: Lessons for Malaysia,' (Paper presented, $5^{\text {th }}$ International Conference on Law and Society, Pattani, Thailand, 18-19 April 2016).

Mohd Zaidi Md Zain, 'Tuntutan Fasakh: Kajian Dari Perspektif UndangUndang Tatacara Mal,' Journal of Shariah Law Research, vol. 3/1 (2018): 1-34.

Narizan Abdul Rahman, 'Isu-Isu dan Masalah Perundangan Mahkamah Syariah' (Kertas kerja Penyelidikan Intensification of Research in Priority Areas, Balai Ilmu Akademi Pengajian Islam, Universiti Malaya, 30 Ogos 2005), 1-25.

Othman Lebar, Penyelidikan Kualitatif: Pengenalan kepada Teori dan Metode (Perak: Penerbit Universiti Pendidikan Sultan Idris, 2015).

Raihanah Hj. Abdullah, 'Alasan Membubarkan Perkahwinan Melalui Fasakh,' Jurnal Syariah, vol. 5/1 (1997): 51-62.

Raihanah Abdullah, 'Penangguhan Kes di Mahkamah Syariah: Cabaran dan Penyelesaian,' Jurnal Syariah, vol. 17/1 (2009): 17-19.

Richard A. Krueger, Focus Groups: A Practical Guide for Applied Research (Thousand Oaks: Sage Publications, 1994).

Robert C. Bogdan \& Sari K. Biklen, Qualitative Research for Education: An Introduction to Theory and Methods (Boston: Allyn \& Bacon, 2003).

Robert E. Stake, The Art of Case Study Research: Perspective in Practice (Thousand Oaks, CA: Sage Publishing, 1995).

Siti Zubaidah Ismail, Ilhaamie Abdul Ghani Azmi \& Zulfikri Yasoa, 'Justice Delayed is Justice Denied?: Divorce Case Management in Malaysian Shariah Court' Proceeding International Conference on Management (Penang: ICM, 2011), 977-987.

Suseela Malakolunthu, 'Pengumpulan dan Analisis Data Kualitatif: Satu Imbasan,' dalam Penyelidikan Kualitatif, ed. Marohaini Yusoff (Kuala Lumpur: Penerbit Universiti Malaya, 2001), 121-132. 
Suwaid Tapah, 'Undang-Undang Mal di Malaysia,' dalam Mahkamah Syariah di Malaysia: Pencapaian dan Cabaran, ed. Ahmad Hidayat Buang (Kuala Lumpur: Penerbit Universiti Malaya, 2005), 23-24.

Suzaini Mohd Saufi \& Najibah Mohd Zin, ‘An Empirical Study on Women's Plight in Ta'liq and Fasakh Proceedings in the Malaysian Syariah Court' (Paper presented, 1st International Conference on Women and Children Legal and Social Issues, Subang, Selangor, 17-18 October 2016).

Theresa Kline, Psychological Testing: A Practical Approach to Design and Evaluation (California: Sage Publication, 2005). 